\title{
Endovascular treatment of aortic arch aneurysms
}

\author{
Tratamento endovascular dos aneurismas de arco aórtico \\ Roberto Chiesa, Germano Melissano, Yamume Tshomba, Efrem Civilini, Enrico Maria Marone, \\ Luca Bertoglio, Fabio Massimo Calliari, Bruno Di Bernardo*
}

\begin{abstract}
Background: Endovascular approach to the aortic arch is an appealing solution for selected patients.

Objective: To compare the technical and clinical success recorded in the different anatomical settings of endografting for aortic arch disease.

Methods: Between June 1999 and October 2006, among 178 patients treated at our institution for thoracic aorta disease with a stent-graft, the aortic arch was involved in 64 cases. According to the classification proposed by Ishimaru, aortic zone 0 was involved in 14 cases, zone 1 in 12 cases and zone 2 in 38 cases. A hybrid surgical procedure of supra-aortic debranching and revascularization was performed in 37 cases.
\end{abstract}

Results: Zone 0. Proximal neck length: $44 \pm 6 \mathrm{~mm}$. Initial clinical success was 78.6\%: two deaths (stroke), one type Ia endoleak. At a mean follow-up of $16.4 \pm 11$ months the midterm clinical success was $85.7 \%$. Zone 1. Proximal neck length: $28 \pm 5 \mathrm{~mm}$. Initial clinical success was $66.7 \%$ : 0 deaths, four type Ia endoleaks. At a mean follow-up of $16.9 \pm 17.2$ months the midterm clinical success was $75.0 \%$. Zone 2 . Proximal neck length: $30 \pm 5 \mathrm{~mm}$. Initial clinical success was $84.2 \%$ : two deaths (one cardiac arrest, one multiorgan embolization), three type Ia endoleaks, one case of open conversion. Two cases of delayed transitory paraparesis/paraplegia were observed. At a mean follow-up of $28.0 \pm 17.2$ months the midterm clinical success was $89.5 \%$.

Conclusions: This study and a literature review demonstrated that hybrid procedure for aortic arch pathology is feasible in selected patients at high risk for conventional surgery. Our experience is still limited by the relatively small sample size. We propose to reserve zone 1 for patients unfit for sternotomy or in cases with aortic neck length $>30 \mathrm{~mm}$ following left common carotid artery debranching. We recommend to perform complete aortic rerouting of the aortic arch in cases with lesser comorbidities and shorter aortic neck.

Keywords: Aortic arch, endovascular treatment, stent-graft, hybrid procedure.

\section{Resumo}

Contexto: O tratamento endovascular dos aneurismas do arco aórtico é uma solução interessante para pacientes selecionados.

Objetivo: Comparar os sucessos técnico e clínico registrados nas diferentes regiões anatômicas do arco aórtico após a colocação de endoprótese.

Métodos: Entre junho de 1999 e outubro de 2006, 178 pacientes foram tratados na nossa instituição devido a doenças da aorta torácica com a colocação de endoprótese, sendo que o arco aórtico estava envolvido em 64 casos. De acordo com a classificação proposta por Ishimaru, a zona aórtica 0 estava envolvida em 14 casos, zona 1 em 12 casos e zona 2 em 38 casos. Procedimentos de debranching do arco aórtico e revascularização extra-anatômica dos troncos supra-aórticos foram realizados em 37 casos para obter um adequado colo aórtico proximal.

Resultados: Zona 0. Comprimento do colo proximal: $44 \pm 6 \mathrm{~mm}$. Sucesso clínico inicial de 78,6\%: dois óbitos (acidente vascular cerebral), um vazamento do tipo Ia. Seguimento médio de $16,4 \pm 11$ meses com sucesso clínico a médio prazo de $85,7 \%$. Zona 1 . Comprimento do colo proximal: $28 \pm 5 \mathrm{~mm}$. Sucesso clínico inicial de $66,7 \%$ : 0 óbitos, quatro vazamentos do tipo Ia. Seguimento médio de $16,9 \pm 17,2$ meses com sucesso clínico a médio prazo de $75 \%$. Zona 2 . Comprimento do colo proximal: $30 \pm 5 \mathrm{~mm}$. Sucesso clínico inicial de $84,2 \%$ : dois óbitos (um infarto cardíaco e uma embolização de múltiplos órgãos), três vazamentos do tipo Ia, um caso de conversão para operação aberta. Dois casos de paraparesia/paraplegia transitória tardia foram observados. Seguimento médio de 28,0 017,2 meses com sucesso clínico a médio prazo de $89,5 \%$.

Conclusão: Este estudo e a análise da literatura demonstram que o procedimento híbrido para moléstia do arco aórtico é factível em pacientes selecionados com alto risco para a operação convencional. Nossa experiência ainda é limitada pelo tamanho relativamente pequeno da amostra. Sugerimos reservar a zona 1 para pacientes inadequados para esternotomia ou em casos de comprimento do colo aórtico proximal $>30 \mathrm{~mm}$ apos revascularização da artéria carótida comum esquerda. Sugerimos realizar revascularização completa do arco aórtico em pacientes adequados com um colo aórtico proximal mais curto.

Palavras-chave: Arco aórtico, tratamento endovascular, endoprótese, procedimento híbrido.

* Department of Vascular Surgery, Vita-Salute University, Scientific Institute H. San Raffaele, Milan, Italy.

No conflicts of interest declared concerning the publication of this article.

Manuscript received Dec 18, 2007, accepted for publication Apr 15, 2008.

J Vasc Bras. 2008;7(2):90-98.

Copyright $\odot 2008$ by Sociedade Brasileira de Angiologia e de Cirurgia Vascular 


\section{Introduction}

A surgical approach to the aortic arch has been made possible for the first time in the 1960's by the introduction of cardiopulmonary bypass with deep hypothermia and circulatory arrest. ${ }^{1}$ Despite improved results of open repair of the aortic arch with the aid of selective antegrade cerebral perfusion, complications remain high. Moreover, the presence of different preoperative comorbidities are associated with particularly poorer outcomes at univariate and multivariate analysis. ${ }^{2}$ Such patients, ineligible for elective open repair, may benefit from an alternative approach.

The progress with branched stent-grafts that allow a totally endovascular approach has been slow, ${ }^{2,3}$ therefore, nowadays, in order to provide a less invasive treatment that could also be offered to patients unfit for conventional surgery, a hybrid approach consisting of aortic arch debranching with rerouting of the supraaortic trunks and aneurysm exclusion employing straight stent-grafts is still advisable. The availability of stentgrafts that can be easily delivered and deployed in the aortic arch and that can accommodate its curved anatomy have prompted many authors ${ }^{3-10}$ to use them in this challenging alternative choice.

In this study we analyze our results with aortic arch aneurysm stent-graft repair in the different aortic arch zones, ranging from total rerouting of all the supraaortic branches through median sternotomy (total arch debranching) to extra-anatomic revascularization of the left common carotid or the sole subclavian artery (hemiarch debranching), according to the extent of the pathology into the aortic arch and to the availability of an adequate stent-graft landing zone.

\section{Methods}

Between January 1999 and October 2006, 178 patients underwent endovascular grafting of the thoracic aorta at our institution. The aortic arch was involved in 64 cases. There were 56 men and eight women with mean age of 69.6 \pm 11.3 years (range 25-86 years). Atherosclerotic aneurysm was observed in 53 cases, posttraumatic aortic rupture in two cases, aortic dissection in three cases, penetrating ulcer/intramural haematoma

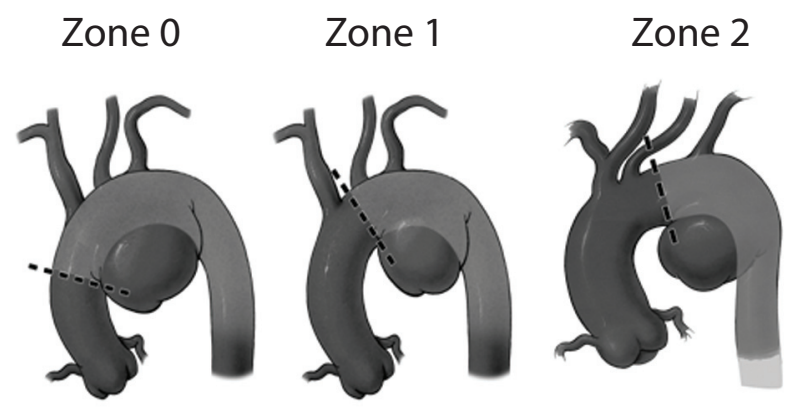

Figure 1 - Ishimaru classification of proximal landing zones

in three cases, pseudoaneurysm in two cases, and stentgraft collapse due to multiple stent fractures in one case.

An additional surgical procedure of supra-aortic debranching and revascularization was performed in 37 cases to obtain an adequate proximal aortic landing zone (PLZ) and in four cases to achieve a satisfactorily access site. According to the classification proposed by Ishimaru, ${ }^{11}$ patients were divided into three groups based on the PLZ involved (Figure 1): zone 0 - 14 cases (13 males; mean age: $73.4 \pm 5.3$ years); zone $1-12$ cases (nine males; mean age: $66.7 \pm 11.8$ years); and zone 2,38 cases (34 males; mean age: 70.4 \pm 12.1 years).

Risk factors of patients in the different groups are reported in Table 1. Two patients were treated urgently for symptomatic disease (one case of zone 1, and one case of zone 2) and two patients emergently for true rupture (two cases of zone 2).

The feasibility of the endoluminal intervention, sizing of stent-grafts and implant strategy were determined preoperatively, mainly using 16-row multislice computed tomography (CT) with multiplanar reconstructions (Aquilion 16; Toshiba Medical Systems). We considered the proximal aortic neck adequate to be a suitable PLZ when the maximum diameter was $\leq 38 \mathrm{~mm}$, and the length was $\geq 20 \mathrm{~mm}$. We used one of several different commercially available stent-grafts (Table 2).

All patients received preoperative duplex scanning of the iliac, femoral, carotid and vertebral arteries to assess access site and to evaluate the vertebral and carotid circulation. 
Table 1 - Preoperative risk factors in the different three groups of patients based to the proximal stent-graft landing zone

\begin{tabular}{|c|c|c|c|c|}
\hline & $\begin{array}{c}\text { Zone } 0 \\
(n=14)\end{array}$ & $\begin{array}{l}\text { Zone } 1 \\
(n=12)\end{array}$ & $\begin{array}{l}\text { Zone } 2 \\
(n=38)\end{array}$ & $\begin{array}{c}\text { Total } \\
(n=64)\end{array}$ \\
\hline Age & $73.4 \pm 5.3$ & $66.7 \pm 11.8$ & $70.4 \pm 12.1$ & $70.4 \pm 10.9$ \\
\hline Sex (men) & 13 & 9 & 34 & 56 \\
\hline Tobacco use & 7 & 5 & 19 & 31 \\
\hline Diabetes & 2 & 3 & 5 & 10 \\
\hline Hypertension & 8 & 6 & 22 & 36 \\
\hline Pulmonary disease & 9 & 4 & 21 & 34 \\
\hline Renal disease & 0 & 1 & 9 & 10 \\
\hline Cardiac disease & 8 & 3 & 16 & 27 \\
\hline $\begin{array}{l}\text { Cerebrovascular } \\
\text { disease }\end{array}$ & 2 & 3 & 7 & 12 \\
\hline Previous AAA repair & 0 & 1 & 3 & 4 \\
\hline
\end{tabular}

AAA $=$ abdominal aortic aneurysm.

Table 2 - Different implanted endografts

\begin{tabular}{lcccc}
\hline & $\begin{array}{c}\text { Zone } \mathbf{0} \\
(\mathbf{n = 1 4})\end{array}$ & $\begin{array}{c}\text { Zone 1 } \\
(\mathbf{n = 1 2})\end{array}$ & $\begin{array}{c}\text { Zone 2 } \\
(\mathbf{n = ~ 3 8})\end{array}$ & $\begin{array}{c}\text { Total } \\
(\mathbf{n}=\mathbf{6 4})\end{array}$ \\
\hline Excluder TAG - old device & 0 & 1 & 3 & 4 \\
Excluder TAG - new device & 1 & 0 & 4 & 5 \\
Talent & 0 & 0 & 4 & 4 \\
Endofit & 0 & 1 & 3 & 4 \\
Zenith TX1 & 5 & 3 & 14 & 22 \\
Zenith TX2 & 8 & 7 & 9 & 24 \\
Zenith TXD & 0 & 0 & 1 & 1 \\
\hline
\end{tabular}

Patients were evaluated with post-procedure chest $\mathrm{X}$-ray and contrast CT scans with scheduled follow-up imaging at 1,6 and 12 months, and yearly thereafter. Angiograms were obtained in selected cases (i.e., endoleaks). Clinical follow-up was also performed at regular 6-month intervals.

\section{Procedure}

All the procedures were performed in the operating room, using a portable digital C-arm image intensifier with road-mapping capabilities. Intraoperative transesophageal echocardiography was used selectively in six patients including all dissection cases.

All cases of zone 0 and zone 1 were performed under general anaesthesia. In zone 2, 26 procedures (68\%) were performed under general anaesthesia, while epidural or subarachnoid anaesthesia was used in 12 cases $(32 \%)$. Cerebral activity was monitored by means of continuous electroencephalogram in all cases performed under general anaesthesia. 
Preoperative cerebral spinal fluid drainage (CSFD) was instituted in two selected patients with previous abdominal aortic surgery and postoperatively in two patients developing symptoms of spinal cord ischemia.

In 60 cases the common femoral artery, exposed through an inguinal incision, was used as access vessel (93.8\%), an iliac access was used in two cases (3.1\%) and two cases $(3.1 \%)$ had the device inserted through an infra-renal aortic tube graft during combined surgery for abdominal aortic aneurysm and aortic arch.

The different techniques of supra-aortic vessels debranching have been previously described. ${ }^{3}$ In summary, debranching of supra-aortic vessels was performed for all zone 0 cases via revascularization of the brachiocephalic trunk and left common carotid artery from the ascending aorta (Figure 2). All zone 1 cases received a cervical cross-over carotid bypass to the left common carotid artery associated with revascularization of left subclavian artery (LSA) in two cases (Figure 3). Intentional overstenting of the LSA without revascularization was performed for zone 2 in 27 cases (11 cases of prophylactic revascularization: eight cases of left carotid-subclavian artery bypass, one case of bilateral carotid subclavian artery bypass in a patient with aberrant right subclavian artery, and two cases of subclavian artery transposition). Prophylactic revascularization of LSA was performed when it supplied coronary circulation through the left internal mammary, when the contralateral vertebral artery was inadequate (i.e., hypotrophy), in young patients, left-handed professionals or in cases of previous abdominal aortic surgery to prevent paraplegia. During all phases of endograft deployment pharmacological systemic hypotension was induced; no overpacing or cardiac arrest were used. After deployment a completion aortography was performed. Ballooning was performed selectively. In all the cases a hybrid one-stage procedure was performed.

\section{Results definition}

Reported results and methods are in accordance with the current reporting standards for endovascular aortic repair prepared and revised by the Ad Hoc Committee for Standardized Reporting Practices in Vascular Surgery (SVS/AAVS). Data are shown as number (\%) for

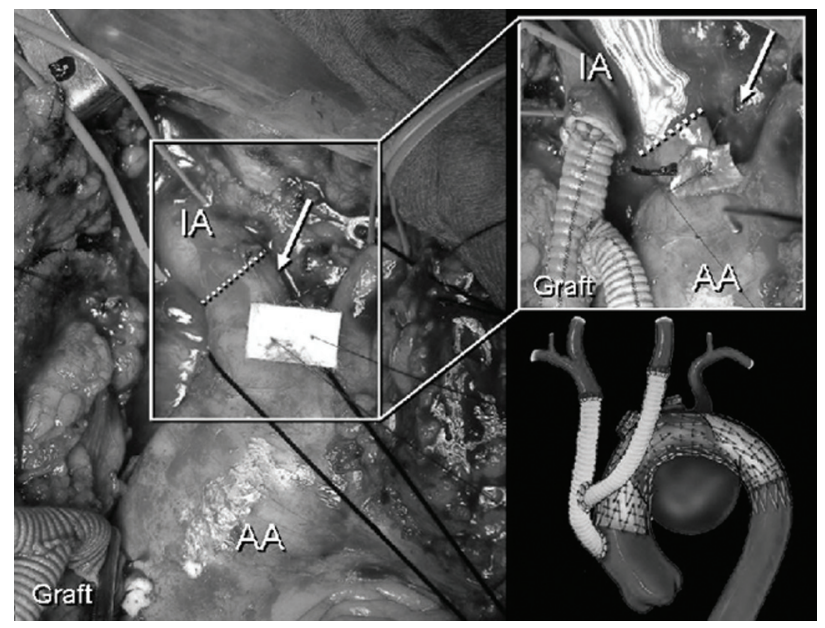

$\mathrm{AA}=$ ascending aorta; $\mathrm{IA}=$ innominate artery.

Figure 2 - Total arch rerouting for zone 0 cases

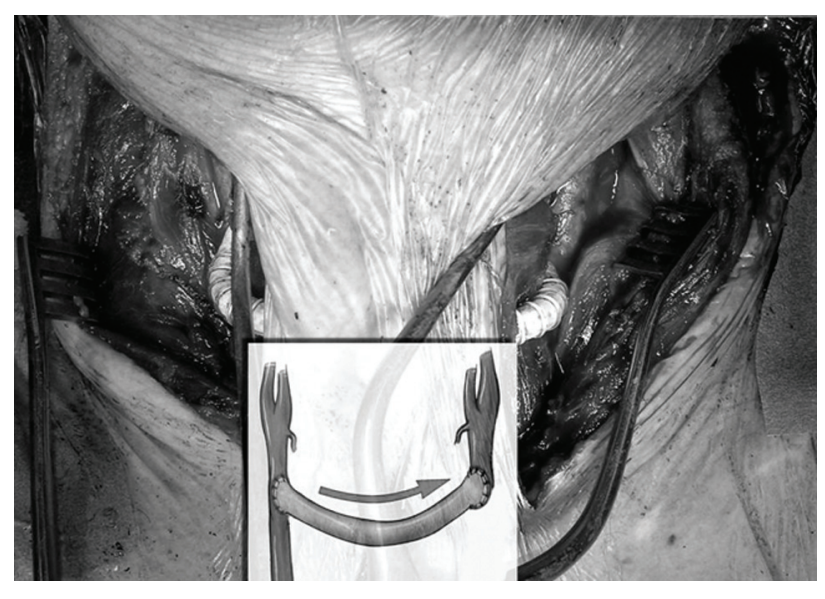

Figure 3 - Hemi-arch rerouting for zone 1 cases

categorical variables or as median, first quartile and third quartile $\left(\mathrm{Q}_{1}-\mathrm{Q}_{3}\right)$ and mean for continuous variables, as they did not show a Gaussian distribution.

\section{Results}

Mean maximum diameter of PLZ was $33.5 \pm 3.7 \mathrm{~mm}$ : $34.3 \pm 3.7 \mathrm{~mm}$ for zone $0,34.1 \pm 3.0 \mathrm{~mm}$ for zone 1 , and $33.0 \pm 3.9 \mathrm{~mm}$ for zone 2. Mean length of PLZ obtained after supra-aortic vessels debranching or intentional coverage of LSA was $33.0 \pm 7.7 \mathrm{~mm}: 43.9 \pm 5.6 \mathrm{~mm}$ for zone $0,28.4 \pm 4.8 \mathrm{~mm}$ for zone 1 , and $30.4 \pm 5.0 \mathrm{~mm}$ for zone 2 . 
Table 3 - Results in the different proximal aortic landing zones

\begin{tabular}{|c|c|c|c|c|}
\hline & $\begin{array}{c}\text { Zone } 0 \\
(n=14)\end{array}$ & $\begin{array}{c}\text { Zone } 1 \\
(n=12)\end{array}$ & $\begin{array}{c}\text { Zone } 2 \\
(n=38)\end{array}$ & $\begin{array}{c}\text { Total } \\
(n=64)\end{array}$ \\
\hline Technical success & $13(92.9 \%)$ & $8(66.7 \%)$ & $34(89.5 \%)$ & $55(85.9 \%)$ \\
\hline Type I or III endoleak & $1(7.1 \%)$ & $4(33.3 \%)$ & $3(7.9 \%)$ & $8(12.5 \%)$ \\
\hline Intraoperative death & 0 & 0 & $1(2.6 \%)$ & $1(1.6 \%)$ \\
\hline Procedural open conversion & 0 & 0 & 0 & 0 \\
\hline 30-day mortality & $2(14.3 \%)$ & 0 & $2(5.3 \%)$ & $4(6.3 \%)$ \\
\hline Paraplegia & 0 & 0 & $2(5.3 \%)$ & $2(3.1 \%)$ \\
\hline Stroke & $2(14.3 \%)$ & 0 & 0 & $2(3.1 \%)$ \\
\hline Renal failure & 0 & 0 & $1(2.6 \%)$ & $1(1.6 \%)$ \\
\hline Respiratory failure & $1(7.1 \%)$ & 0 & 0 & $1(1.6 \%)$ \\
\hline ICU stay & $6.4 \pm 8.5 \mathrm{~d}$ & $2.3 \pm 3.6 \mathrm{~d}$ & $0.7 \pm 1.1 \mathrm{~d}$ & $2.2 \pm 4.8 \mathrm{~d}$ \\
\hline Length hospital stay & $11.1 \pm 8.1 \mathrm{~d}$ & $7.7 \pm 4.4 \mathrm{~d}$ & $4.8 \pm 3.2 \mathrm{~d}$ & $6.7 \pm 5.5 \mathrm{~d}$ \\
\hline Initial clinical success & $11(78.6 \%)$ & $8(66.7 \%)$ & $32(84.2 \%)$ & $51(79.7 \%)$ \\
\hline 30-day open conversion & 0 & 0 & $1(2.6 \%)$ & $1(1.6 \%)$ \\
\hline Short clinical success & $12(85.7 \%)$ & $11(91.7 \%)$ & $35(92.1 \%)$ & $58(90.6 \%)$ \\
\hline Resolution postoperative type I endoleak & $1(7.1 \%)$ & $3(25.0 \%)$ & $3(7.9 \%)$ & $7(18.4 \%)$ \\
\hline Midterm clinical success & $12(85.7 \%)$ & $9(75.0 \%)$ & $34(89.5 \%)$ & $55(85.9 \%)$ \\
\hline New onset type I or III endoleak & 0 & 0 & 0 & 0 \\
\hline Aneurysm-related deaths & 0 & $2(16.7 \%)$ & 0 & $2(3.1 \%)$ \\
\hline Open conversion & 0 & 0 & $1(2.6 \%)$ & $1(1.6 \%)$ \\
\hline
\end{tabular}

$\mathrm{ICU}=$ intensive care unit.

Overall primary technical success was achieved in $55 / 64$ cases $(85.9 \%)$. One patient died 1 hour after the procedure from cardiac arrest because of migration within the arch aneurysm of the stent-graft, ${ }^{3,12}$ and eight patients (12.5\%) had a residual proximal type I endoleak after deployment in the planned landing zone. Only three endoleaks were noticed after completion angiography and all were evident at predischarge CT scan. These endoleaks were temporarily left untreated because the aortic proximal neck was deemed inadequate for further endovascular procedures or required unplanned supra-aortic vessel debranching procedure. A type II endoleak was observed in three patients (4.7\%).

The overall mean intensive care unit stay and the mean length of hospital stay are summarized in Table 3.

Initial (30 days) clinical success was obtained in 51/64 patients $(79.7 \%)$ with a mortality rate of $4 / 64(6.3 \%)$. The causes of perioperative death were stroke in two cases and multiorgan embolization in one case. One patient (zone 2) electively underwent a successful surgical conversion 2 weeks after the procedure because of stent fracture and graft collapse (Table 3). ${ }^{3,12}$ No adjunctive cerebrovascular accidents were recorded. The major adverse rate, including early deaths and major stroke, was $9.4 \%$ (6/64). Paraplegia was observed in two cases (3.1\%): in all cases paraplegia had a delayed onset (range 1-3 days) and resolved after CSFD institution. ${ }^{13}$ Postoperative complications included acute renal failure reversed without dialysis in one patient (1.6\%) and respiratory failure requiring intubation for more than 48 hours in one patient $(1.6 \%)$.

Short-term clinical success was obtained in 58/64 patients $(90.6 \%)$ : seven cases of proximal type I endoleak 
Table 4 - Review of outcomes of the main series reported in literature (> 10 patients) of aortic arch aneurysm hybrid repair

\begin{tabular}{|c|c|c|c|c|c|c|c|c|c|}
\hline Authors & Cases & $\begin{array}{l}\text { Total } \\
\text { arch }\end{array}$ & Hemi-arch & Device & Death & Stroke & $\begin{array}{c}30 \text { days } \\
\text { conversion }\end{array}$ & $\begin{array}{l}\text { Overall } \\
\text { survival }\end{array}$ & $\begin{array}{c}\text { Mean } \\
\text { follow-up }\end{array}$ \\
\hline Kieffer et al. ${ }^{3}$ & 16 & 8 & 8 & $\mathrm{HM}$ & $4(25 \%)$ & $4(25 \%)$ & $4(25 \%)$ & $56 \%$ & $\begin{array}{c}23 \\
\text { months }\end{array}$ \\
\hline Bergeron et al. ${ }^{7}$ & 25 & 15 & 10 & $\begin{array}{c}\text { GE ,TM, } \\
\text { ZC }\end{array}$ & $2(8 \%)$ & $2(8 \%)$ & 0 & $88 \%$ & $\begin{array}{c}15 \\
\text { months }\end{array}$ \\
\hline Czerny et al. ${ }^{8}$ & 11 & 2 & 9 & $\begin{array}{c}\mathrm{EE}, \mathrm{GE}, \\
\mathrm{TM}\end{array}$ & 0 & 0 & 0 & $100 \%$ & $\begin{array}{c}18 \\
\text { months }\end{array}$ \\
\hline Zhou et al. ${ }^{9}$ & 16 & 11 & 5 & GE & $1(6 \%)$ & 0 & 0 & $94 \%$ & $\begin{array}{c}16 \\
\text { months }\end{array}$ \\
\hline Saleh et al. ${ }^{10}$ & 15 & 15 & 0 & $\mathrm{TM}$ & 0 & 0 & 0 & $93 \%$ & $\begin{array}{c}18 \\
\text { months }\end{array}$ \\
\hline Schumacher et al. ${ }^{6}$ & 25 & 9 & 16 & $\begin{array}{l}\mathrm{EE}, \mathrm{GE}, \\
\mathrm{TM}, \mathrm{ZC}\end{array}$ & $5(20 \%)$ & $1(4 \%)$ & 0 & $76 \%$ & $\begin{array}{c}21 \\
\text { months }\end{array}$ \\
\hline HSR experience & 26 & 14 & 12 & $\begin{array}{l}\mathrm{EE}, \mathrm{GE}, \\
\mathrm{ZC}\end{array}$ & $2(8 \%)$ & $2(8 \%)$ & 0 & $82 \%$ & $\begin{array}{c}19 \\
\text { months }\end{array}$ \\
\hline Total & 134 & 74 & 60 & $\begin{array}{c}\text { CM, EE, } \\
\text { GE, TM, } \\
\text { ZC }\end{array}$ & $\begin{array}{c}14 \\
(10.5 \%)\end{array}$ & $9(6.7 \%)$ & $4(3.0 \%)$ & $83.1 \%$ & $\begin{array}{l}\text { r. } 15-23 \\
\text { months }\end{array}$ \\
\hline
\end{tabular}

$\mathrm{CM}=$ custom-made; $\mathrm{EE}=$ Endofit Endomed; $\mathrm{GE}=$ Gore TAG Excluder; $\mathrm{HM}=$ home-made device; HSR = Scientific Institute H. San Raffaele; TM = Talent Medtronic; $\mathrm{ZC}=$ Zenith Cook.

resolved completely without any further intervention and one case of perioperative endoleak is being followed 2 months after the procedure (Table 3).

At a mean follow-up of $19.1 \pm 15.6$ months (range $1-65$ months), there was midterm clinical success in 55/64 patients $(85.9 \%)$.

Two patients died from aneurysm rupture (zone 1) and one surgical conversion was performed because of a late fracture of the longitudinal support wire of a Gore Excluder TAG stent-graft 43 months after endovascular procedure for zone 2 aneurysm. We also recorded two late deaths unrelated to the aneurysm.

\section{Discussion}

In the 1990's, when cerebral perfusion was introduced as an adjunct during aortic arch open repair, a significant outcome improvement was reported. Several authors $^{2,5,8}$ have reported very significant outcome improvements and reduced mortality with these techniques. However, these excellent results require an accurate patient selection, a great technical experience in cardiac and thoracic aortic surgery, "high-volume" activity, and are not reproduced in many centres throughout the world.

Despite improved results of open repair of the aortic arch with the aid of selective cerebral perfusion, the leading causes of early postoperative mortality are still permanent cerebral dysfunction, myocardial failure and bleeding. Different case reports have demonstrated the technical feasibility of total or hemi-arch rerouting of the supra-aortic branches associated with endovascular treatment of aortic arch pathology, but only a few studies including more than 10 cases have been published (Table 4). 
We previously reported our initial experience on hybrid treatment of aortic arch pathology. ${ }^{4}$ From analysis of results of our overall contemporary experience, we reported a mortality rate of $6.3 \%$ and a stroke rate of $3.1 \%$, however, initial clinical success rates are less satisfactorily than the results published for endovascular treatment of descending thoracic aortic pathology. The initial clinical success rate of our series has been affected by a high rate of type I endoleaks. Consistently with the reports of other authors, ${ }^{3,7,8}$ we observed complete spontaneous resolution of these type I endoleaks within the first 6 months with an acceptable short and midterm clinical success rate. Type I endoleaks were discovered after a satisfactorily positioned endograft with adequate proximal neck length and could be related to incomplete endograft seal in the proximal neck possibly due to high blood stream flow. This may explain the high rate of spontaneous resolution in our series within the first 6 months of follow-up.

Although zone 2 is anatomically an aortic arch segment, it represents a very peculiar pattern of aortic arch disease with specific troubles and features. These "borderline" landing zones between the descending thoracic aorta and the aortic arch present some concerns typical of aortic arch and also of descending aortic stent-graft repair. They should be likely considered a specific separate pattern of disease and the definition of aortic arch stent-graft repair should be limited to the landing zones 1 and 0 .

Management of the LSA arising from zone 2 PLZ remains a debated issue. ${ }^{4,5,14-16}$ In our practice we intentionally overstented the LSA with revascularization only in selected cases. Unlike other authors, ${ }^{15,16}$ we did not observe complications related to LSA occlusion. The only postoperative death in this PLZ was due to multiorgan embolization (cerebral and limbs) in a case of thoracic shaggy aorta. The neurological morbidity we recorded was delayed onset paraplegia in two cases of extensive descending thoracic aorta involvement. In this two cases a prompt CSFD institution completely resolved the spinal cord ischemia. Tiessenhausen et al. ${ }^{17}$ proposed prophylactic revascularization of the LSA to prevent paraplegia in case of extensive thoracic aorta involvement and in previous abdominal aortic surgery.
For zone 1 hemi-arch debranching with extraanatomical revascularization of the left common carotid has been performed, followed by overstenting of its origin. ${ }^{3-9}$ This technical solution, in our experience, produced no mortality, however short and midterm clinical success was less satisfactory than in the other PLZ. This difference was not statistically significant, possibly due to sample size. The lower success rate is due to an excessive rate of immediate type I endoleak and to the two aneurysm-related deaths at midterm follow-up. The less satisfactory results in zone 1 group may be related to the shorter aortic neck length obtained rerouting blood flow only to the left common carotid artery and to the proximity of aortic arch major angulation. Initially, we judged an aortic proximal neck length $\geq 20 \mathrm{~mm}$ to be sufficient for endografting in the zone 1 in order to avoid sternotomy and complete rerouting of aortic arch. Currently we choose zone 1 PLZ if the aortic neck length was $>30 \mathrm{~mm}$ or in patients absolutely unfit for sternotomy with shorter aortic necks. Another concern of endovascular treatment of zone 1 PLZ is the durability of the extrathoracic revascularization of the left common carotid artery. In fact, experience derived from treatment of obstructive disease of supra-aortic vessels showed that long-term patency of extrathoracic reconstruction was lower that intrathoracic anatomical reconstructions. ${ }^{18}$ An interesting alternative proposed by Czerny et al. ${ }^{8}$ is to perform revascularization of left common carotid and subclavian artery for zone 1 with intrathoracic autologous double transposition. This approach, however, requires the invasiveness of a median sternotomy and does not provide any advantage in terms of proximal aortic neck gained compared with a total arch debranching feasible with a median sternotomy.

Complete rerouting of the aortic arch was reported in the literature but only few centres have presented series of more than 10 cases (Table 4). Kieffer et al. ${ }^{3}$ reported the first large series on 16 cases of zone 0 and 1 , employing a homemade stent-graft with mortality, perioperative morbidity and conversion rates of 25, 62.5 and $12.5 \%$, respectively. Schumacher et al. ${ }^{6}$ reported more encouraging results with commercially available endografts: in their recently updated series of 25 high risk patients affected by an aortic arch aneurysm, they recorded two deaths in seven zone 0 cases. More recently 
four large series ${ }^{7-10}$ were published involving 43 zone 0 cases with only three deaths reported. No cerebrovascular accidents were described. Our updated experience in zone $0^{3}$ confirmed that the procedure can be performed safely and with reasonably technical success rate; however, the main drawback in our series were cerebrovascular accidents. Our two deaths were related to fatal stroke. This evidence differs from other published series in which all deaths were mainly related to complication of endovascular procedures itself (i.e., guide-wire or device tip ventricle perforation, iliac rupture, etc.).

A controversial issue is timing of supra-aortic debranching and endovascular procedure. Some authors ${ }^{7,8,10}$ prefer to perform a staged procedure with a free interval, ranging from 1 to 3 weeks, between open surgery and endovascular procedure. We prefer to perform both the procedures in the same operation for several reasons. A single general anesthesia is required that gives us the advantage to easily use an aortoiliac access when needed. Moreover, adjunctive surgical maneuvers, such as aortic banding or more proximal ligature of supra-aortic stumps, can be performed selectively to correct type I endoleak. Saleh et al. ${ }^{10}$ performed routinely aortic banding of proximal aortic neck in a staged approach strategy, however this adjunctive maneuver carries some risks of surrounding tissue damage and we suggest to perform only if required after endograft deployment (i.e., endoleaks). Furthermore, a single stage approach does not leave a time at risk of rupture between the complete recovery from median sternotomy and endovascular procedure.

\section{Conclusion}

Overall, this study and literature review demonstrated that hybrid procedure for aortic arch pathology is feasible in selected patients at high risk for conventional surgery. The outcomes are promising, but nowadays mortality and morbidity rates cannot be neglected.

Our experience is still limited by the relatively small sample size. However, the analysis of our results may have practical implications on the ongoing evolution of hybrid procedures in the aortic arch. Currently we propose to reserve zone 1 for patients unfit for sternotomy or in cases with aortic neck length $>30 \mathrm{~mm}$ following left common carotid artery debranching and we recommend to perform complete aortic rerouting of the aortic arch in cases with lesser comorbidities and shorter aortic neck.

This recommendation, standardization of procedures, technological evolution of materials, and stentgrafts will probably improve initial and midterm clinical success rate. Moreover, hybrid treatment of aortic arch pathology may be reserved to patients unfit for open repair.

\section{References}

1. Piwnica A, Weiss M, Lenfant C, Dubost C. Circulatory arrest and deep hypothermia induced with a pump oxygenator system and a heat exchanger. J Cardiovasc Surg (Torino). 1960;1:74-84.

2. Di Eusanio M, Schepens MA, Morshuis WJ, et al. Brain protection using antegrade selective cerebral perfusion: a multicenter study. Ann Thorac Surg. 2003;76:1181-8.

3. Kieffer E, Koskas F, Cluzel PH, Benhamou A, Bahnini A, Chiche L. Endoluminal repair of the aortic arch combined with revascularization of supra-aortic arteries. In: Branchereau A, Jacobs M, editors. EVC 2004 hybrid vascular procedures. Malden: Blackwell Publishing; 2005. p. 75-84.

4. Melissano G, Civilini E, Bertoglio L, Setacci F, Chiesa R. Endovascular treatment of aortic arch aneurysms. Eur J Vasc Endovasc Surg. 2005;29:131-8.

5. Criado FJ, Abul-Khoudoud OR, Domer GS, et al. Endovascular repair of the thoracic aorta: lessons learned. Ann Thorac Surg. 2005;80:857-63.

6. Schumacher H, Von Tengg-Kobligk H, Ostovic M, et al. Hybrid aortic procedures for endoluminal arch replacement in thoracic aneurysms and type B dissections. J Cardiovasc Surg (Torino). 2006;47:509-17.

7. Bergeron P, Mangialardi N, Costa P, et al. Great vessel management for endovascular exclusion of aortic arch aneurysms and dissections. Eur J Vasc Endovasc Surg. 2006;32:38-45

8. Czerny M, Gottardi R, Zimpfer D, et al. Transposition of the supraaortic branches for extended endovascular arch repair. Eur J Cardiothorac Surg. 2006;29:709-13.

9. Zhou W, Reardon M, Peden EK, Lin PH, Lumsden AB. Hybrid approach to complex thoracic aortic aneurysms in high-risk patients: surgical challenges and clinical outcomes. J Vasc Surg. 2006;44:688-93.

10. Saleh HM, Inglese L. Combined surgical and endovascular treatment of aortic arch aneurysms. J Vasc Surg. 2006:44:460-6

11. Mitchell RS, Ishimaru S, Ehrlich MP, et al. First International Summit on Thoracic Aortic Endografting: roundtable on thoracic aortic dissection as an indication for endografting. J Endovasc Ther. 2002;9:98-105. 
12. Melissano G, Tshomba Y, Civilini E, Chiesa R. Disappointing results with a new commercially available thoracic endograft. J Vasc Surg. 2004;39:124-30.

13. Chiesa R, Melissano G, Marrocco-Trischitta MM, Civilini E, Setacci F. Spinal cord ischemia after elective stent-graft repair of the thoracic aorta. J Vasc Surg. 2005;42:11-7.

14. Gorich J, Asquan Y, Seifarth H, et al. Initial experience with intentional stent-graft coverage of the subclavian artery during endovascular thoracic aortic repairs. J Endovasc Ther. 2002;9 Suppl 2:II39-43.

15. Peterson BG, Eskandari MK, Gleason TG, Morasch MD. Utility of left subclavian artery revascularization in association with endoluminal repair of acute and chronic thoracic aortic pathology. J Vasc Surg. 2006;43:433-9.

16. Fattori R, Nienaber CA, Rousseau H, et al. Results of endovascular repair of the thoracic aorta with the Talent thoracic stent graft: the Talent Thoracic Retrospective Registry. J Thorac Cardiovasc Surg. 2006;132:332-9.
17. Tiesenhausen K, Hausegger KA, Oberwalder P, et al. Left subclavian artery management in endovascular repair of thoracic aortic aneurysms and aortic dissections. J Card Surg. 2003;18:429-35.

18. Takach TJ, Reul GJ, Cooley DA, et al. Brachiocephalic reconstruction I: operative and long-term results for complex disease. J Vasc Surg. 2005;42:47-54.

Correspondence:

Prof. Roberto Chiesa

Department of Vascular Surgery, IRCCS H. San

Raffaele

Via Olgettina, 60

20132 - Milan - Italy

Tel.: +39 (02) 2643.7130

Fax: +39 (02) 2643.7148

E-mail: r.chiesa@hsr.it

XVII Congreso Argentino de Cirugía Cardiovascular y Endovascular

V Congreso de Cirugía Cardiovascular del Cono Sur

II Congreso Argentino de Instrumentación en Cirugía Cardiovascular

4,5 y 6 de setiembre de 2008

Hotel Alejandro $\mathrm{I}^{\circ}$

Salta, Argentina

www.congreso.caccv.org 